\title{
Çevre Etiğinde Özgün Bir Yaklaşım: Ricardo Rozzi ve Biyokültürel Etik*
}

\author{
Murat ARTUÇ**
}

$\ddot{O} \mathbf{z}$

Biyokültürel etik başlığı altında Ricardo Rozzi; çevre etiğine özgün bir bakış getirmektedir. Biyokültürel etik; bilimsel ekolojik bilgiyi ana akım Batı felsefesi dışında kalan felsefe ve dünya görüşleri ile birleștirmeyi amaçlamıştır. Modern bilim ve felsefe tüm dünyayı kapsamakta ve yerel unsurları görmezden gelmektedir. Biyokültürel etik ise bu tutuma karşı yerel değer, bilgi ve felsefenin önemine vurgu yaparak insan ve doğanın özellikle aydınlanma sonrası gelişen felsefe ve bilimden ancak biyokültürel çeşitlilikle korunabileceğini ifade etmektedir. Rozzi; Aldo Leopold ve Luisa Maffi gibi düşünürler yanında And Dağları'ndaki yerli toplumların ekolojik bilgi ve kültürlerinden de etkilenmiştir. Ayrıca F. S. Chapin'in "Yeryüzü Naipliği” yaklaşımının da biyokültürel etiğin önemli bir parçası veya bir öncülü olduğunu söylemek mümkündür. Bu makalede Rozzi'nin Biyokültürel Etik yaklaşımı ele alınmaktadır. Makalenin yazımı sürecinde literatür taraması yoluyla elde edilen veriler kullanılmaktadır.

Anahtar Kelimeler: Çevre Etiği, Ekoloji, Biyokültürel Etik, Ricardo Rozzi, Biyokültürel Türdeșleșme

\section{A Distinctive Approach to Environmental Ethics: Ricardo Rozzi and Biocultural Ethics}

\begin{abstract}
Ricardo Rozzi under the title of biocultural ethics; brings an original perspective to environmental ethics. Biocultural ethics aims to combine scientific ecological knowledge with philosophy and worldviews that are outside the mainstream Western philosophy. Modern science and philosophy cover the whole world and mostly ignores local counterparts. Biocultural ethics, on the other hand, emphasizes the importance of local value, knowledge and philosophy against this attitude, and states that cultural diversity and nature should be protected from philosophy and science developed after enlightenment. In addition to thinkers like Aldo Leopold and Luisa Maffi; Rozzi was also

Özgün Araştırma Makalesi (Original Research Article)

Geliş/Received: 19.12 .2019

Kabul/Accepted: 25.06 .2020

DOI: https://dx.doi.org/10.17336/igusbd.660881

* Bu makale, 2017 yılında önerisi kabul edilen ve Doç. Dr. Yunus Emre ÖZER danışmanlığında Dokuz Eylül Üniversitesi, Sosyal Bilimler Enstitüsü, Kamu Yönetimi Anabilim Dalı'nda hazırlanmakta olan "İklim Değişikliğinin Etik Boyutları" başlıklı doktora tezinden türetilmiştir.

** Arş. Gör., Aydın Adnan Menderes Üniversitesi, Nazilli İktisadi ve İdari Bilimler Fakültesi, Siyaset Bilimi ve Kamu Yönetimi Bölümü, Aydın, Türkiye. E-posta: murat.artuc@adu.edu.tr ORCID https://orcid.org/0000-0001-9816-4166
\end{abstract}


influenced by the ecological knowledge and cultures of indigenous communities in the Andes. Also, it's possible to claim that the "Earth Stewardship" concept of F. S. Chapin is a major part or an antecedent to Biocultural Ethics. In this article, Rozzi's approach of Biocultural Ethics is discussed. The data obtained through literature review is used during the writing process of the article.

Keywords: Environmental Ethics, Ecology, Biocultural Ethics, Ricardo Rozzi, Biocultural Homogenization

\section{Giriş}

Etik kelimesinin kökeni olan "ethos"; aslında Antik Yunanca'da ilk olarak bir mekânı tarif etmek için kullanılmıştır. Bu mekân bir hayvanın yaşam alanı, evi, yuvasıdır. Daha sonraki insanların yaşam alanları için de aynı kavram kullanılmaya başlanmıştır. Kavram sonraları bir fiil haline gelmiş ve bir yere yerleșip orada yașamak anlamında kullanılmıştır. Fakat kelimenin bu anlamlarda kullanılması Aristo'nun çalışmalarından itibaren ortadan kaybolmuştur. Aristo, ethos kelimesini yalnızca insanlar için kullanmakta ve insanlar dışındaki canlıları ve habitatları dikkate almamaktadır (Rozzi, 2013b, s. 20-21).

Etiğin yalnızca insanlar ve insanlar arası ilişkileri ele alıyor olmasını günümüze dek yaşanan çevresel trajedilerin kaynaklarından biri olarak görmek mümkündür. Schweitzer insanın düşündüğü için var olduğunu savlayan Descartes'in yaklaşımını fazlaca soyut bulmaktadır. Bunu somutlaştırmak için sorulacak soru insanın neyi düşündügüdür. İnsan düşünüyorsa bu düşüncenin bir de içeriği olmalıdır (Schweitzer, 1998, s. 155-156).

Bir insanın çevreyle ilgili bir etiğin var olması gerektiğinden kuşku duyması ancak hiçbir etiğe inanmaması halinde mümkün olabilir. İnsanlar çevresel koşullardan hem fayda hem de zarar görmektedir. İnsanların yaşam kalitesi için tek başına yeterli olmasa da çevrenin kalitesi gerekli bir unsurdur. İnsanların dünyasında toprak, hava, su, fotosentez ve iklim gibi ekolojik kaynaklar; yașam ve ölüm meselesidir. Neyimiz varsa aslında doğada yetişmiş ya da doğadan elde edilmiştir. Kültür ve doğa iç içe girmiştir ve birbirinden ayrılamaz. Bu nedenle etiğin çevreye de uygulanması gerekir. Elbette sadece insan etiğini çevresel ilişkilere uygulamak; arzu edilen bir şey değildir. Çevre etiği son kertede yalnızca kaynakların kullanımı, fayda ve maliyetin adil dağıtımı ve riskler, kirlenme düzeyleri, haklar ve cezalar, gelecek nesillerin ihtiyaçları gibi şeyler değildir. Fakat bunların hepsinin çevre etiğinin içinde yer bulduğunu söyleyebiliriz. Bunlar tek başına alındığında çevre etiği insanların çıkarlarının yanında ikincil kalmaktadır. Hâlbuki çevre etiği birincil olmalıdır (Rolston, 1988, s. 1-2).

Çevrenin, etiğin inceleme alanına girişi aslında çok yenidir. Bu nedenle antik çağda da sonraki dönemlerde de doğrudan bir çevre etiği düşünürü gösterme imkânı bulunmamaktadır. Çevrenin ahlaki konumu felsefeye o kadar uzaktır ki; 17. yüzyılın en ünlü düşünürlerinden olan ve Amerikan Anayasası üzerinde büyük etkisi olduğu kabul edilen John Locke bile işlenmemiş araziyi israf olarak görmüş, değersiz kabul etmiştir (Jamieson, 2008, s. 17).

Descartes, Bacon ve Galileo'dan Newton'a kadar Avrupa'nın bilimsel ve felsefi yaklaşımı; birkaç yüzyıllık bir barbarlık olarak nitelendirilebilir. Hiçbir şey kutsal değilmiş, hiçbir șey kendiliğinden saygıya layık değilmiş ya da hiçbir şey kendi başına bir değere ya da onura sahip değilmiş gibi doğaya karşı çok katı bir şekilde yaklaşıyor olmak; bilimsel araştırmalar için büyük bir avantaj sağlamış ve modern doğa bilimlerinde harika sonuçlar vermiştir. Fakat doğayı istismar ederken gösterilen bu katı ve barbarca tavır; hem çevresel yıkımların büyüklüğüne karşı duyarlılığı hem de daha derin nedenlerle 
ilgilenme kapasitesini azaltmıştır. İnsanın gerçekliği kavrayışını olumsuz etkilemiştir (Naess, 1989, s. 185).

Schweitzer kendi dönemine dek bütün etik sistemlerin en büyük zayıflığının; yalnızca insanların insanlarla olan ilişkileriyle ilgilenmek olduğu söylemektedir. Hâlbuki gerçekte sorulması gereken evrene ve onun beslediği tüm şeylere karşı tavrımızın ne olacağıdır (Schweitzer, 1998, s. 157-158).

Çevre etiği kavramının modern düşünce tarihine girişi 1970'li yıllarda gerçekleşmiştir. Bununla beraber Leopold'ün "Yeryüzü Etiği” gibi yaklaşımların çevre ve etik ilişkisini daha geriye götürdügü de söylenebilir. Leopold, etiğin öncelikle insanlar arasındaki ilişkileri ele aldığını söyler. Daha sonra etik insanın toplumla ilişkisini düzenlemeye başlamıştır. İnsanlık uzun geçmişi boyunca yeryüzü ve onun üzerindeki hayvanlar ve bitkilerle insanlar arasındaki ilişkiyi düzenleyen bir etik kuram geliștirmemiștir. Toprak yalnızca mülk olarak görülmektedir ve yalnızca ekonomik niteliklidir. İnsanların ayrıcalıklarını belirtmekte ama insanlara sorumluluklar getirmemektedir. Leopold'e göre etiğin, bu üçüncü unsuru da içine alması bir zorunluluktur (Leopold, 1949: 202-204).

White, çevresel sorunların ruhani ve dini bir temeli olduğunu söylemektedir. Çevresel krizin merkezinde Hristiyanlığın insan merkezli oluşu bulunmaktadır. Elbette çevresel problemler bütün dünyada, Hristiyan olmayan bölgelerde de meydana gelir. Fakat Hristiyanlık çevresel krizin başlıca sorumlusudur. White'a göre Hristiyanlığın Batılı formu, dinler arasında en insanmerkezci olandır. İnsan Tanrı'nın doğa üzerindeki üstünlügünü paylaşmaktadır. Hristiyanlık yalnızca insan ve doğa arasında bir düalizm ortaya koymamış aynı zamanda insanın doğayı sömürmesini Tanrının iradesi olarak nitelemiştir. Pagan inançlarda ise canlıların hatta varlıkların tanrısal bir yanı vardır. Bir hayvanın, ağacın ya da hatta bir dağın bile kendi ruhu vardır. Herkesin kendi içindeki tanrısallığı keşfetmesi amaçlanır. Hristiyanlığın aksine bu geleneklerin hepsi insanmerkezciliği reddeder. Modern bilim ve teknolojinin gelişmesini sağlayan bu insanmerkezciliktir ve bu da çevresel bir krize dönüşmüştür. Çevresel krizler, bu anlayıștan uzaklașılmadığı sürece derinleşmeye devam edecektir (White, 1967 s. 12041206).

Carson insanmerkezci doğa algısına karşı çıkmaktadır. "Doğayı kontrol etme" fikrini küstahça bulur ve bunun biyoloji ve felsefenin neandertal döneminde icat edilmiş, doğanın insanın yararı için var olduğunu savunan bir düşünce olduğunu belirtir (Carson, 1962, s. 297). Günümüzde baskın Batı geleneği doğal dünyanın insanın faydalanması için var olduğu görüşü üzerine kurulmuştur. İnsan besin çemberinin en üstünde yer almaktadır ve bu dünyanın öneme sahip üyeleri yalnızca insanlardır (Taback ve Ramanan, 2014, s. 38-39).

Halbuki günümüz dünyasında etiğin kapsamı temel bir değişikliğe uğramıştır. Platon'dan Kant'a kadar klasik etik metinlerinin yazıldığı dönemlerde, insan eyleminin etkileri, neredeyse tamamen o eylemi yerine getiren kişinin etrafındakilerle sınırlıydı. Uzun dönem çıtılar ise şansa ya da tahmin edilemez yan etkilere bağlanıyor ve erdem ya da görevle ilgili teoriler üretilirken önemli kabul edilmiyordu. Günümüzde ise teknolojinin gelişmişliği nedeniyle insan eylemlerinin biyosferin çok geniş alanlarını ve yüzyıllar boyunca gelecek nesilleri etkileyeceği kabul edilmektedir. Biyosferin geri kalanına karşı görevlerimizin yanı sıra; insan yaşamının gezegenimizdeki devamını sağlamak için geçerli koşulları korumak etik bir sorun hale gelmiștir. Bu nedenle insanların sorumluluklarının kapsamının yeniden belirlenmesi bu yeni ve radikal ortama uyum sağlayacak şekilde yeniden belirlenmesi ve bu şekilde etiğin alanının insan eylemleri ve ihmallerinin etkilerini karşılayacak şekilde genişlemesi gerekmektedir (Attfield, 2010: 183). 
Özetle; Leopold'den önce çevreye ilgi duyan düşünürler, doğayı ancak karmaşıklığı ve içinde güzel bir varlık olarak ele almış ve insan kullanımı nedeniyle zarara uğradığını tespit etmiştir. Henry Thoreau, George Marsh ve John Muir gibi düşünürlerden esinlenen Leopold bir koruma etiği ve sonrasında yeryüzü etiğini ortaya koyan ilk düşünürdür. Leopold sonrası Schweitzer "yaşama saygı" etiğini öne sürmüş ve insanların tüm yaşamlara yardım etmek istediğini söylemiştir. Rachel Carson insanların yalnızca diğer insanlarla ilişkilerini ele almanın yetersiz olduğunu söylemektedir. İnsanların tüm yaşamlarla ilişkisi üzerinde durmuștur. 1970’lerde Naess derin ekoloji düşüncesiyle insan merkezli bir bakış açısını reddetmiştir. Sonraki çeyrek asırda etik yaklaşımlar insanmerkezci bakış açısından uzaklaşma devam etmiştir. Bunlara örnek olarak Potter'ın biyoetik ve "küresel biyoetik" yaklaşımları, Griffin'in postmodern etiği verilebilir (Leopold, 2004, s.152).

Bu makalede ele alınan Rozzi'nin biyokültürel etik teorisi de kültür, çevre ve etik içerikli bir teori ortaya koymaktadır. Makalenin amacı ülkemizde pek bilinmeyen bu yaklaşımın literatürümüze kazandırılmasıdır. Ayrıca biyokültürel etiğin savlarının tartışılarak geliştirilmesi ve karar alıcılara fayda sağlaması da hedeflenmektedir.

\section{Biyokültürel Etik}

Güney Amerika'daki yerli topluluklarla birlikte çalışan Şilili bir ekolojist ve felsefeci olan Rozzi, ekolojik bilimler ve çevre felsefesini birleștirmiştir. Bu sayede çağdaş bilimsel bilgi ile yerel ekolojik bilgi arasındaki benzerlikleri ve farklılıkları daha iyi anlamak amacıyla bir epistemolojik ve etik çerçeve geliștirmiștir. Rozzi'nin çalıșmaları farklı sosyokültürel aktörler arasındaki iletişimi ve saygıyı güçlendirme ve biyokültürel korumayı destekleme amacına yöneliktir (Rozzi, 2009b, s. 267).

Biyokültürel etiğe giden yolu açıklarken, Rozzi And dağlarındaki yerli kabilelerin düşünce ve bilgisini araştırdığını anlatmaktadır. Rozzi, bilimsel yöntemlerle ulaşılan sonuçlara, yerli topluluklar tarafından üretilen ekolojik bilginin de ulaştığını tespit etmektedir. Buna karşın ülkede bu yerli ekolojik bilginin öğretildiği bir eğitim kurumu bulunmamaktadır. Buradan hareket ederek Rozzi; üniversitelerde okutulan evrensel bilim yaklaşımının yerine, epistemolojilerin çoklu evrenini ve ekolojik bilginin farklı türlerini anladığını belirtmektedir. Rozzi yerli kabilelere yaptığı ziyaretler ve kurduğu ilişkiler sayesinde bu kültürün doğa ile uyumu ve birlikteliğine şahit olmuştur. Aynı birlikteliğin Batı düşüncesinin en erken dönemlerinde de görülebileceğini belirtmektedir. Rozzi'ye göre biyokültürel mozaiğin daha iyi anlaşllı; küresel eğitsel, yönetsel ve ekonomik sistemlerde benimsenmesi bölgesel sürdürülebilir kültürlerin devam etmesini destekleyen politikalar doğuracaktır. Bunun yanında bu benimseme küresel ve heterojen bir sürdürülebilir birlikte yașam meta kültürüne temel olabilir (Rozzi ve Massardo, 2011, s. 246-247).

Rozzi, bilim ve felsefe arasında bir köprü kurmak istemektedir. Rozzi'ye (1999) göre ekolojistler bir kültürün daha sağlam hale gelmesine ya da dönüșmesine katkı sağlayabilir. Ekolojistler toplumun doğaya karşı tavrını belirlemekte merkezi bir rol üstlenir. Bilimsel teoriler ve çevresel etik arasındaki uyum üzerine eleştirel düşünceler getirmek küresel çevresel krize karşı mücadeleye katkı sağlar. Bilim ve etik arasındaki içsel ilişkiyi de içeren bir yaklaşım; baskın ekonomik ve araçsal paradigmaya bağlı kalmaktan da kaçınılmasını sağlar. Günümüzde piyasa ekonomisi küreselleşmekteyse de, aslında yalnızca bilmek ve yaşamakla ilgili sonsuz olası paradigmalardan bir tanesidir. Ekolojik ve etik unsurları birlikte değerlendirebilen bir yaklaşım ekolojistler ve felsefecilerin birlikte analiz yapabilmelerini sağlar.

Ekolojistlerin teorilerini belli etik değerleri dikkate alarak kurdukları ve etikçilerin de doğaya belli bilimsel teoriler ışığında değer verdikleri birleştirici bir 
perspektifle; objektif bilgi ve sübjektif ahlak arasındaki bölünme aşllabilir. Bu sayede teori ve uygulama arasındaki bağlantı ile doğa hakkında bilgi sahibi olma ve doğal dünyada yaşamanın yolları arasındaki bağlantı yeniden kurulabilir (Rozzi, 1999, s. 919-920).

Rozzi "Yeryüzü" kelimesi üzerinde durmaktadır. Bu kelime bir yandan biyofiziksel dünyayı anlatmakta iken bir yandan da kültürel bir gerçeklikten söz etmektedir. Bilim insanları çoğunlukla birinci anlam üzerinde dururken filozoflar da genellikle "yeryüzü" kelimesinin ikinci kullanımını dikkate almaktadır. Biyokültürel etik bu farklı iki kullanımı bir araya getirmek istemektedir. Dolayısıyla biyokültürel etik biyolojik ve fiziksel dünyayı insanlığın kültürel kazanımlarıyla bir araya getirmektedir (Rozzi, 2015a, s. 88).

Biyokültürel etik; Rozzi tarafından 3H olarak kısaltılan, davranışlar (habits) ve habitat ve habitattaki diğer sakinlerin (co-in-Habitants) esenliği ve kimliği arasında bağ kurma ve bu yolla küreselleşmenin sosyal ve ekolojik sonuçlarını değerlendirme ve onlara yeni bir yön vermeyi içerir. Elbette bu etiğin biyofizik, sembolik, dilbilimsel ve kurumsalsosyoekonomik, teknolojik boyutları olacaktır. Ayrıca biyokültürel etik; Sokrates öncesi ve diğer ana akım olmayan Batı düşüncesi, Amerikan yerlisi ve Batılı olmayan diğer ekolojik dünya görüşleri ve çağdaş ekolojik-evrimsel bilimler üzerine temellendirilmiştir (Rozzi, 2013a, s. 3-4).

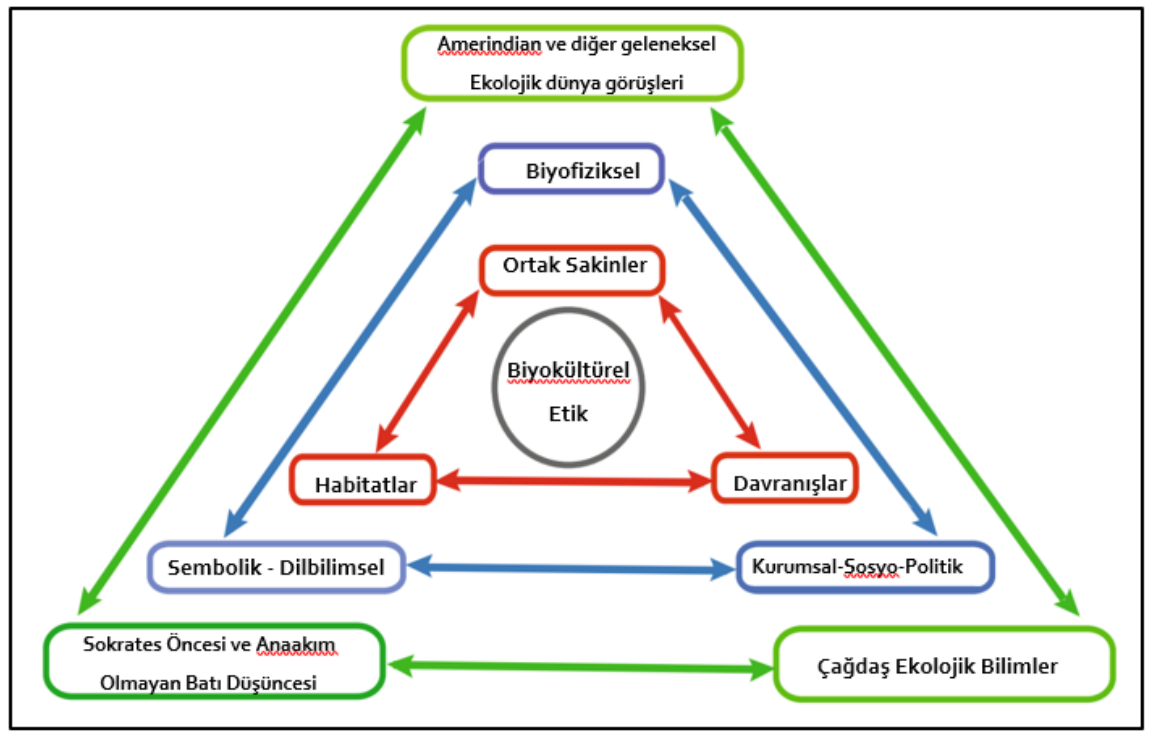

Şekil 1: Biyokültürel Etik Şeması (Rozzi, 2013b, s. 11).

Daha önce de değinildiği üzere Rozzi'nin ana akım Batı düşüncesini itina ile yaklaşımının dışında tuttuğunu kolaylıkla görmek mümkündür. Kendisi ana akım Batı düşüncesinin etik teorilerini de eleştirmektedir.

Rozzi (2013b) Biyokültürel etiğin, mevcut etik anlayışı dönüştüren yeni paradigmayı şu nedenlere bağlamaktadır:

- Deontolojik ve yararcı etiklerin insanmerkezciliği yerine biyokültürel etik insan yaşamı ile varlıkların çeşitliliğini birbirine bağlar. Bu çeşitlilik; insanların kimliklerini ve esenliklerini birlikte inşa ettikleri sakinleri ifade eder. Biyokültürel etik yararcı etiğin ya da deontolojik etiğin hayvanları, bitkileri ya da diğer canlıları içermek için genişletilmesi ve bunları ahlaken ilgili varlıklar olarak içermeye çalışması çabası değildir. Biyokültürel 
etik; geleneksel Batı etiğinin “İnsan dünyaya nasıl yerleşmeli?” sorusunu insanların diğer canlılarla birlikte dünyaya nasıl yerleșmesi gerektiği sorusu ile değiştirir.

- Biyokültürel etik Leopold'ün Yeryüzü etiğiyle de farklılık gösterir. Leopold'e göre insanın rolü değişmiş ve yeryüzü toplumunun sade bir üyesi ve vatandaşı haline gelmiştir. Halbuki Biyokültürel etik göstermektedir ki; pek çok kültürün ekolojik dünya görüşüne göre insan, bitkiler, sular ve diğer varlıklar yeryüzünün birlikte sakinleridir. Bu nedenle biyokültürel etik kültürler arası diyalog istemektedir. Yeni küresel çevresel değişme belli unsurların (sosyal gruplar, şirketler, bireyler) etkisiyle gerçekleşmiştir. Bu sonuç bütün türe yani tüm insanlara genellenemez. İnsan ve insan olmayan varlıkların yaşamına zarar veren sürdürülemez uygulamalar yasaklanmalı ve sonuçları giderilmelidir. Bunu tamamlayıcı olarak; küresel sosyal ve çevresel değişim bağlamında, dünya görüşleri, bilgi formları, değerler ve kültürlerin sürdürülebilir ekolojik uygulamalarına saygı duyulmalı ve kültürlerarası değişimle bunlar diğer kültürlere uyarlanmalıdır.

- Ana akım modern etiğin habitatı dikkate almadan insan davranışına odaklanmış bakıș açısının aksine; biyokültürel etik insan davranıșını habitatı ve habitattaki diğer canlı topluluklarını birbiriyle eșleștirir. Bu unsurlar biyofizik, sembolik-dilbilimsel ve kurumsal, sosyo-politik ve teknolojik alanları içerir. Her bir alan içinde güç ve çevresel sorunların çözümü için farklılaştırılmış sorumlulukların ilişkisi dikkate alınmalıdır. Bunlar sadece betimleyici ifadeler değildir; aksine pratik gerçeğe arzuyu da içeren normatif ifadelerdir. Biyokültürel etik; biyolojik ve kültürel çeşitliliği koruyarak ekososyal adalete katkı sağlamayı amaçlar (Rozzi, 2013b, s. 10-11).

Habitat ve insan davranışı arasındaki karşılıklı ilişki anlayıșının düzeltilmesi pek çok felsefeci için açık bir konu değildir. Çünkü modern deontolojik ve yararcı etik; etik konuları evrensel terimlerle ele alır. Biyokültürel etik baskın modern etiklerden farklı olduğu kadar mevcut çevre etiklerinden de ayrılır. Bu yaklaşım "Post-Leopoldcü" olarak adlandırılabilecek, kültürel çeşitliliğin önemini anlayan bir paradigma önermektedir. Leopold etik için Batı tarihi boyunca ilerleyen çizgisel bir gelişim süreci tanımlamaktadır. Hâlbuki biyokültürel etik tarihin çizgisel olmadığına vurgu yapar. Çünkü çoklu biyokültürel dünya görüşleri ve etikleri Batı medeniyetinin ötesinde, geçmişte ya da günümüzde, aynı anda farklı gruplarda bulunabilir (Rozzi, 2013b, s. 19).

Biyokültürel etiğin önemli bir bileșeni "Biyokültürel Türdeşleşme (Biocultural Homogenization)" kavramıdır. Egzotik türler (Introduced Species) insanlar tarafından kasıtlı ya da kasıtsız olarak bir bölgeden bağlantılı olmayan başka bir bölgeye taşınan türler olarak tanımlanabilir. İnsanlar egzotik türleri taşıma işini çok uzun zamandır yapmaktadır (Simberloff, 2013b, s. 34). İște bu egzotik türlerin istilacı davranışları nedeniyle yerli ekosistem baskı altına girebilir.

Rozzi "Biyokültürel türdeșleşme (Biocultural homogenization)" olarak tanımladığı bu olguyu eleştirmektedir. Biyokültürel türdeşleşme; bitki örtüsü, dil ve felsefe gibi alanlarda tek tipleșme ve türdeșleșmedir. Dünyanın en ücra kentlerinde bile kentsel alanda palmiye ağaçları bulunmakta, 7000'e yakın dil arasından sadece 7 tanesi yaygın olarak konuşulmakta ve okullarda Avrupamerkezci bir felsefe öğretilmektedir. Bu türdeşleşme aslında neoliberal düşüncenin biyoçeşitliliği bir "tabii kaynak" olarak gören anlayışını türdeşleştirmektedir. Hâlbuki bu anlayışın dev ekonomik projeleri (büyük madenler, hidroelektrik santraller) biyolojik ve kültürel çeşitliliğin büyük ölçeklerde kaybına neden olmakta ve aynı zamanda sosyal ve çevresel adaletsizliğe yol açmaktadır. İşte biyokültürel etik bu trende karşı bazı bölgesel habitatlarının ve yaşam tarzlarının korunmasının insanlar ve diğer ortak sakinlerin esenliği ve kimliği için çok önemli olduğunu anlayan bir ekolojik, felsefi ve kavramsal çerçeve ile ortaya çıkmaktadır (Rozzi, 2013b, s. 12-19). 
Biyokültürel türdeşleşme eşzamanlı ve karşıbağımlı bir şekilde biyolojik ve kültürel çeşitliliğin yerel, bölgesel ve küresel ölçekte ortadan kalması sürecidir. Bu süreç yerel kültürlerin ve habitatların birlikte evrimleşme ilişkilerini bozmaktadır. Çoğunlukla küresel türdeş davranışlara maruz kalan bir insanın küresel türdeş habitatlar inşa edeceği ve küresel türdeş yaşam tarzları ve düşünce tipleri uygulayacağını kabul etmek durumundayız (Rozzi vd., 2018, s. 2-3).

Biyokültürel türdeşleşmenin itici güçlerinden birisi de kırdan kente göçtür. İnsanların atalarından miras kalan yeryüzüne geleneksel olarak gösterdikleri ilgi, bakım ve onu kullanma şeklinin yerini; geniş ölçekli madenciliğe ve toprak mülkiyetini daha az insan üzerinde toplamaya odaklı bir tek kültürlülügün genişlemesine bırakmasına neden olmaktadır. Ayrıca kırdan kente göçen kitleler bölgesel, kültürel ve biyolojik çeşitliliklerini kaybetmektedir (Rozzi, 2013b, s 14-16).

Biyokültürel etikte dilbilimsel çeşitlilik önemli bir yer tutar. Rozzi; insanların doğa ile ilgili iletişim kurarken özelleștirilmiş bir dil kullandığın söyler. Bu dil yerel ekolojik bilgi ve uygulamaları da içine alır. Biyolojik çeşitliliği algılamak ve anlamak dil, kültür ve teknolojiyle ilgilidir. "Biyokültürel" kelimesi kişinin kültürel lenslerle baktığını ifade etmektedir. Bu lensler insanların yaşayan canlıları ve süreçleri nasıl değiștirdiğini de etkiler. Biyolojik çeşitliliğin farklı dillerdeki çoklu temsil ve sınıflandırmasına yönelik bir anlayıș geliștirerek Avrupa ve Kuzey Amerika'da baskın olan, doğaya ekonomikmatematik temelli yaklaşımın yapısı sökülebilir. Bu sayede ekolojik bilgi ve uygulamaların alternatif türlerine dikkat çekilebilir (Rozzi, 2009a, s. 100-101).

Rozzi biyokültürel etiğin yalnızca felsefe ve bilimsel düşünce ürünü bir akademik tartışma olmasını değil; çevre politikalarına entegre bir uygulamalı etik teorisi olmasını da istemektedir. Bu bağlamda çevre politikalarının yerel, ulusal ve küresel ölçekte biyokültürel etikten beslenmesi arzu edilmektedir.

Biyokültürel etiğin kavramsal çerçevesi; bir yandan yaşam, sürdürülebilir uygulamalar ve düşük çevresel etki konusunda farklı etik değerlere sahip kültürel gelenekleri olan farklı toplulukların (kentler, kırsal ya da ücra bölgeler) bulunduğunu; diğer yandan kısa dönem kârlılığı, sürdürülebilir olmayan uygulamalar ve uygunsuz ölçüde yüksek çevresel etkilere yol açan değerlere sahip özneler bulunduğunu da ayrıca kabul etmektedir. Bu nedenle teknik ve etik açıdan çeşitli sosyal gruplar, şirketler ve uluslar arasında farklılaştırılmış sorumlulukların belirlenmesi ve uygulanması doğru olacaktır. Bu unsurlar günümüzde karşı karşıya kaldığımız sosyal ve çevresel negatif sonuçlara ciddi oranda katkıda bulunmuştur (Rozzi, 2015b, s. 113).

\section{Tartışma ve Değerlendirme}

Biyokültürel etik; büyük çevresel yıkımlar ve küresel çevre problemleri ile yüz yüze kalan toplumların çevre politikası araçlarını kullanırken faydalanabilecekleri felsefi bir değerler seti sunmaktadır. Bu değerler seti günümüzdeki bu çevresel krize neden olan ve halen doğaya yalnızca ekonomik lenslerle bakan baskın Batı kültürünün değerlerinden farklıdır. Rozzi; küreselleşme karşısında kendi kültürüne bağlı kalmaya çalışan yerli toplulukların, artık konuşanı çok az kalmış ve unutulmaya yüz tutmuş lisanların, kültürle iç içe girmiş ve türdeşleşme tehlikesiyle karşı karşıya olan ekosistemlerin içinde bir araya geldiği bir etik önerisinde bulunmaktadır.

Bu öneri ele alındığında ilk olarak hem büyük bir avantaj ve hem de büyük bir dezavantaja sahip olduğu görülmektedir. Biyokültürel etik bir yandan evrensel olan bilimsel, ekolojik veriyi sahiplenirken; diğer yandan da kültürel anlamda göreci (rölativist) bir yaklaşım ortaya koymaktadır. Aslında evrenselciliğin (üniversalizm) çoğu kez yerel ve kültürel unsurlara kucak açabileceği zaten söylenmektedir ama Rozzi'nin bu 
konuda fazlasıyla evrensellikten kaçındığını ve hatta teorisini tamamen evrenselcilik karşıtlığı üzerine konumlandırdığı görülmektedir.

Biyokültürel etiğin en büyük dezavantajı ise yerel kültüre ve değerlere aşırı bir güven duymasında saklıdır. Rozzi Şilili olan, eserlerinde Şili'nin yerli kültürüne pek çok atıf yapan ve etiğini kurgularken özellikle Amerindian kültüre büyük önem veren bir düşünürdür. Yukarıda değinildiği üzere; "Sokrates öncesi ve diğer ana akım olmayan Batı düşüncesi, Amerikan yerlisi ve Batıll olmayan diğer ekolojik dünya görüşleri ve çağdaş ekolojik-evrimsel bilimler" temeli üzerine teorisini inşa ederek, modern Batı kültür ve medeniyetini devre dışı bırakmayı amaçlamıştır. Bu da söz konusu temelin; modern ekoloji biliminin verileriyle donanmıș, akıllı ve sorumlu bir öznenin sorumluluklarıyla ne kadar uzlaşır bir temel olduğu sorusunun cevabını içermemektedir. Bunun da ötesinde sınır aşan çevresel krizlerde farklı toplumların aynı soruna nasıl birlikte çözüm arayacağı, bu konuda iç dinamiklerinin ne kadar yeterli olacağı da tartışılması gereken bir husustur.

Ayrıca çağdaş ekolojinin epistemolojik dayanağının ve bilimsel yöntemlerinin de teoride dışlanan Batı düşüncesi kaynaklı olması nedeniyle teorinin kendi içinde felsefi bir çelişki yaşadığı da öne sürülebilir. Bilimsel çalıșma ve gelișmelerde bilim felsefesinin önemli rolünü gözden kaçırmamak gerekmektedir. Buna karşın Rozzi'nin bilginin üretimi aşamasında tek bir yöntemi değil; çoklu alternatif bilgiler sistemine dayanan bir bilgi üretim şemasını savunduğu düşünüldügünde bu çelişki ortadan kalkmaktadır.

Çevresel çözüm politikalarının başarılı olması için toplumsal destek görmeleri gerekir. Toplumsal destek ve politikaların benimsenmesi ile bu çözümlerin kültürle uyumu arasında da bir bağlantı kurulabilir. Baskın ekonomi temelli yaklaşımlar yerine; çevre-insan ilişkisini gelenek ve inançlarla beslenmiş, yerel bir dünya görüşüyle kaynaşmıș bilimsel ekolojik bilgi ile ele almak geniș bir toplumsal tabana yayılmış çevre politikaları üretimine katkı sağlayabilir.

Biyokültürel etik; çevre için kültürün, kültür için de çevrenin korunması gerektiğini savlayan bir teoridir. Teorinin ana gövdesi sabit kalsa da esnekliği nedeniyle uygulamasının toplumsal durumsallıkla başa çıkma kapasitesinin yüksek olduğu da söylenebilir.

Biyokültürel türdeşleşmenin ülkemizde de deneyimlenen bir olgu olduğu kolaylıkla söylenebilir. Hemen her kentimizde kentsel dekorasyon için kullanılan palmiye ağaçları bile tek başına bu durumu göstermek için yeterlidir. Ekonomik değerin, kalan değerler koleksiyonunun bütününü önemsizleștirdiği ve öznelliğin yalnızlığına terk ettiği bir dönemde biyokültürel etik yerel ve geleneksel bilgi ve değerlerin yeniden canlanması için bir dayanak noktası oluşturabilir. Bu değerlerin çevreyle ilişkisi kurularak toplum tarafından kolaylıkla benimsenebilecek ve uygulanabilecek bir insan-çevre ilişkisi çerçevesini çizmek mümkün olabilecektir.

\section{KAYNAKÇA}

CARSON, R. (1962a). Silent Spring. 50th Year Anniversary Edition. Mariner Books. Houghton Mifflin Harcourt. 2012.

JAMIESON, D. (2008). Ethics and the Environment: An Introduction. Cambridge University Press.

LEOPOLD, A. (1949). A Sand County Almanac and Sketches Here and There. American Museum of Natural History. Special Members' Edition. Oxford University Press.

LEOPOLD, A.C. (2004). Living with the Land Ethic. BioScience. Cilt: 54, Sayl: 2.

NAESS, A. (1989). From Ecology to Ecosophy, From Science to Wisdom. World Futures: The Journal of New Paradigm Research. 27: 2-4. 
ROLSTON, H. III. (1988). Environmental Ethics: Duties to and Values in the Natural World. Temple University Press. Philadelphia.

ROZZI, R. (1999). The Reciprocal Links between Evolutionary-Ecological Sciences and Environmental Ethics. Bioscience. Cilt: 49, Sayı: 11.

ROZZI, R. (2009a). Biocultural and Linguistic Diversity. Editörler: Callicott, J.B. ve Frodeman, R.. Encyclopedia Of Environmental Ethics And Philosophy. Gale: Cengage Learning.

ROZZI, R. (2009b). South America. Editörler: Callicott, J.B. ve Frodeman, R.. Encyclopedia Of Environmental Ethics And Philosophy. Gale: Cengage Learning.

ROZZI, R. ve MASSARDO, F. (2011). The Road to Biocultural Ethics. Frontiers in Ecology and the Environment. Cilt 9, Sayı 4.

ROZZI, R. (2013a). Biocultural Ethics: From Biocultural Homogenization Toward Biocultural Conservation. Rozzi, R., Pickett, S.T.A., Palmer, C., Armesto, J.J., Callicott, J.B. (Ed.) Linking Ecology and Ethics for a Changing World: Values, Philosophy, and Action. Springer.

ROZZI, R. (2013b). Introduction to Integrating Philosophy and Ecology:

Biocultural Interfaces. Rozzi, R., Pickett, S.T.A., Palmer, C., Armesto, J.J., Callicott, J.B. (Ed.) Linking Ecology and Ethics for a Changing World: Values, Philosophy, and Action. Springer.

ROZZI, R. (2015a). Earth Stewardship and the Biocultural Ethic: Latin American Perspectives, Editörler: Rozzi, R., Chapin, F.S. III, Callicott, J.B., Pickett S.T.A., Power, M.E., Armesto, J.J., May Jr, R.H.. Earth Stewardship Linking Ecology and Ethics in Theory and Practice, Springer.

ROZZI, R. vd. (2018). From Biocultural Homogenization to Biocultural Conservation: A Conceptual Framework to Reorient Society Toward Sustainability of Life. Editörler: Rozzi, R., May Jr., R.H., Chapin III, F.S., Massarado, F., Gavin, M.C., Klaver, I.J., Pauchard, A., Nuñez, M.A., Simberloff, D.. From Biocultural Homogenization to Biocultural Conservation. Springer.

SCHWEITZER, A. (1998). Out of My Life and Thought: An Autobiography. Çeviri: A. B. Lemke (1990). The Johns Hopkins University Press. Londra.

SIMBERLOFF, D. (2013). Introduced Species, Homogenizing Biotas and Cultures. Rozzi, R., Pickett, S.T.A., Palmer, C., Armesto, J.J., Callicott, J.B. (Ed.) Linking Ecology and Ethics for a Changing World: Values, Philosophy, and Action. Springer.

TABACK, H. ve RAMANAN, R. (2014). Environmental Ethics and Sustainability: A Casebook for Environmental Professionals. CRC Press. Taylor \& Francis.

WHITE, L.T.J. (1967). The Historical Roots of Our Ecologic Crisis. Science. Cilt: 155, Sayi: 3767.

\section{Summary}

Environmental ethics includes many different and diverse theories as a field of study. One of these theories is the Biocultural Ethics developed by Ricardo Rozzi.

Rozzi intends to present an alternative theory in today's world where Western civilization represents the dominant worldview. In creating this alternative, Rozzi turns his back on the mainstream modern Western thought and aims to combine the data obtained from ecological sciences with non-mainstream Western thought, and especially with indigenous world views.

The goal of biocultural ethics is not only to protect nature, but also the preservation of the diversity of local cultures and languages. These elements produce the philosophy that will protect nature. In this context, this approach also opposes the homogenization of the dominant worldview, which considers the environment only as an economic resource. Of 
course, as well as cultural homogenization, biological homogenization is mentioned as an area of critique by the theory.

Biocultural ethics aims to be a model that can be applied to local, regional, and global environmental problems. A strong part of this model is that the societies that do not adopt Western civilization have the potential to combine scientific knowledge with their own world views and develop policies against environmental crises.

On the other hand, the fact that the theory is new yet causes an underdeveloped appearance in comparison with the mainstream ethical theories with centuries of history. Biocultural ethics is an approach that needs to be discussed and developed and its applicability to environmental crises in many parts of the world needs to be tested. 